\title{
Twist and Shout, or Back to the Sixties
}

\author{
James B. Bullard
}

$\mathrm{T}$

he Federal Open Market Committee (FOMC) has increased the target federal funds rate at each meeting since June 2004, to 2.5 percent following the February 2005 meeting. A puzzling aspect of recent financial market developments has been that, despite the rise of 150 basis points in the Fed's target rate, longer-term rates have remained roughly constant. In recent testimony, Fed Chairman Alan Greenspan commented extensively on this issue, eventually concluding that the market behavior "remains a conundrum." 1

There was a time when this same behavior would not have been considered so unusual. It occurred in the early 1960s, a cherished era among monetary economists and policymakers. That era sported relatively rapid growth in both real output and productivity, low inflation rates, and low rates of interest, not unlike the present day. Although many years have passed since that time, the intervening years have been associated with higher inflation - at times substantially higher-and have been dominated by Federal Reserve efforts to move inflation lower and build credibility for continued low inflation. The low level of inflation and high level of Fed credibility characteristic of the early 1960s returned in the early 2000s. Thus, the early 1960s may give a better indication of the nature of today's financial markets than most of the intervening years.

The chart shows the evolution of short- and longer-term interest rates during the 38 months following the last month of the recession relevant to each era. The most recent recession ended in November 2001, while for the earlier era it ended in February 1961. The chart shows the effective federal funds rate along with the longer-term 10-year Treasury note yield. The most striking characteristic is that in both eras, once the federal funds rate began rising following the recession, the longer-term bond yield remained anchored near 4 percent. One explanation is that, in both eras, the private sector viewed movements in short-term interest rates as exactly those necessary to keep inflation low and steady, so that longer-term inflation expectations and hence longer-term bond yields could remain anchored.

Similarities in the interest rate environment may also be attributable in part to similarities in economic performance. The average annualized quarterly growth rates of key variables were a lot alike during 2002:Q1 to 2004:Q4 as compared with the corresponding 1961:Q2 to 1964:Q4 period. Average nonfarm business sector productivity growth, for instance, was almost identical during the two periods, 3.90 percent today versus 3.80 percent in the early 1960 s. Inflation rates were similar as well, with the core consumer price index increasing, on average, 1.80 percent during the current period versus 1.40 percent during the earlier era. Real output growth was robust in both periods as well, 3.50 percent in the early 2000 s versus 5.40 percent in the early 1960s.

The expansion of the 1960s was one of the longest on record, lasting until December 1969, when a relatively mild recession occurred. Inflation began to rise unexpectedly during the last half of the 1960s, setting the stage for the economically volatile decade to follow. Whether today's FOMC will manage a 1960s-style expansion remains to be seen, but the era may be a good one to learn from given the similar levels of inflation and Fed credibility.

\footnotetext{
${ }^{1}$ Testimony of Chairman Alan Greenspan, Federal Reserve Board's semiannual Monetary Policy Report to the Congress Before the Committee on Banking, Housing, and Urban Affairs, U.S. Senate, February 16, 2005.
}

\section{Interest Rates, Then and Now}

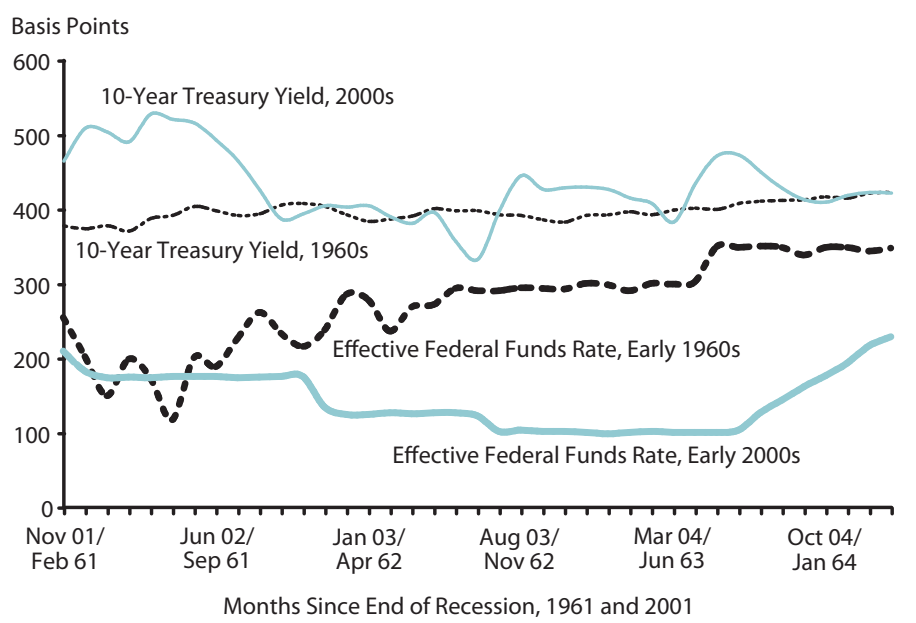

